\title{
Спонтанний розрив стравоходу: нестандартна ситуація в діагностиці та лікуванні
}

\author{
V. O. SHAPRYNSKYI, V. F. KRYVETSKYI, V. I. POLISHCHUK, YE. V. SHAPRYNSKYI, B. O. MITIUK
}

Vinnytsia National Medical University by M. I. Pyrohov

Vinnytsia Regional Clinical Hospital by M. I. Pyrohov

\section{SPONTANEOUS RUPTURE OF THE ESOPHAGEES: NON-STANDARD SITUATION IN DIAGNOSIS AND TREATMENT}

Перфорації стравоходу належать до смертельно небезпечних захворювань. Серед усіх можливих варіантів даної патології окреме місце за тяжкістю діагностування та надання допомоги займає спонтанний розрив.

За останні 15 років у хірургічній клініці на базі торакального відділення Вінницької ОКЛ лікувались 11 хворих із спонтанним розривом: усі - чоловіки віком від 35 до 64 років.

Лише один пацієнт був доставлений у спеціалізований стаціонар протягом першої доби, решта - в строки від 2 до 14 діб з моменту виникнення захворювання. У всіх випадках спостерігався розвиток медіастиніту, що поєднувався з емпіємою плеври (зліва -5 , справа - 1, з обох боків -6). В одного хворого мав місце некроз стінки правого головного бронха.

Одинадцять хворих були оперовані. Ще один госпіталізований в термінальному стані, допомога обмежувалась дренуванням плевральних порожнин та реанімаційними заходами. Зашивання дефекту проведено в 7 випадках (4- з лапаротомного, 3-лівобічного торакотомного доступу). Виключення стравоходу та декомпресію шлунка забезпечували гастростомією. Дренування середостіння і плевральних порожнин проводили роздільно широкопросвітними трубками.

Вперше спонтанний розрив стравоходу описаний в 1724 p. Boerhaave, який спостерігав поперечний, найбільш рідкісний варіант. Пізніше, в 1788 р., Dryden описав поздовжній розрив. В обох випадках діагноз було встановлено при патологоанатомічному дослідженні після смерті хворого. Пріоритет прижиттєвого діагнозу даного ушкодження належить Meyrs (1858 p.).

Найчастіше самовільний розрив стравоходу виникає в нижній третині грудного відділу (наддіафрагмальний та ретрокардіальний сегменти) - у 85 \% випадків, при цьому на лівій стінці у - $80 \%$, на правій - у 16 \% та на передній - у 4 \%). Рідше дефект виникає в середній третині грудного відділу, нижче непарної вени (14 \% хворих) чи інших місцях (у $1 \%$ спостережень). Причиною спонтанного розриву стравоходу вважається раптове підвищення внутрішньостравохідного тиску під час натужування, частіше при блюванні (при цьому порушується координоване відкриття сфінктерів стравоходу). Виникненню розриву сприяють анатомічні особливості будови стінки стравоходу, кровопостачання, іннервації, сегментарні дефекти циркулярних м'язів стінки стравоходу, запальні зміни стінки.

У перебізі характерною є раптова поява, зазвичай під час блювання, болю за грудниною чи в надчеревній ділянці, який віддає в поперек, ліве плече. Хворий блідне, вкривається холодним потом, настають задишка, сильна спрага, тахікардія. Дуже швидко виникає повітряна емфізема середостіння, що розповсюджується на клітковинні простори шиї, через лічені години розвивається і прогресує медіастиніт. Спонтанний розрив може ускладнюватись пневмотораксом, піопневмотораксом, перикардитом, емпіємою плеври, пневмонією, що супроводжуються відповідною клінікою. Характерним є руйнування медіастинальної плеври. Гемодинамічні розлади корелюють із глибиною шоку та рівнем інтоксикації.

Основу діагностики спонтанного розриву складає рентгенологічне дослідження. На оглядовій рентгенограмі виявляють різні прояви газового синдрому (пневмомедіастинум, підшкірна повітряна емфізема, пневмоторакс, пневмоплеврит), медіастиніту (розширення тінісередостіння, поява медіастинальних рівнів), екстрамедіастинальних ускладнень. Для верифікації діагнозу проводять контрастування стравоходу водорозчинними препаратами, з виявленням виходу контрасту в середостіння та плевральну порожнину.

Серед наших спостережень убільшості хворих біль раптово виник у епігастрії та за грудниною під час блювання, в одного - при кашлі та одночасному 
нахилі тулуба вперед, ще раз - під час їди. В половини пацієнтів спостерігали стравохідну кровотечу, двічі - інтенсивну. У всіх випадках відзначали виражену задишку, тахікардію, зниження артеріального тиску, блідість шкірних покривів, прогресуючу повітряну емфізему шиі. Після виконання рентгенографії органів грудної клітки розширення тіні середостіння, емфізему середостіння, плевральні ускладнення було виявлено у всіх випадках. Під час контрастування стравоходу водорозчинним контрастом останній потрапляв у середостіння, а потім - у плевральну порожнину. У 10 спостереженнях розрив локалізувався в наддіафрагмальному сегменті зліва, в одному - справа в підбронхіальному сегменті.

Варто вказати, що у вказаного контингенту хворих дуже часто на етапах доспеціалізованої допомоги помилково діагностуються перфорація виразки шлунка, інфаркт міокарда, розшаровуюча аневризма аорти, панкреатит, пневмоторакс. Труднощі диференціювання значно відстрочують початок адекватного лікування.

Основу лікування синдрому Боргааве складає операційне втручання, що передбачає реалізацію кількох складових: адекватного роздільного полідренування середостіння, ураженої плевральної порожнини i клітковинних просторів; виключення стравоходу шляхом накладання гастростоми чи ентеростоми; а також - оптимально - ушивання розриву стравоходу.

У клініці прийнято ізольовувати стравохід за рахунок формування декомпресійної гастростоми 3 ентеральним зондом для харчування. Середостіння дренували спареними трубками, роздільно від плевральної порожнини. Зашивання дефекту стравохідної стінки виконували пошарово атравматичними голками, при використанні лапаротомного доступу з фундокардіопластикою.

Медикаментозна терапія полягала у призначенні антибактеріальної, дезінтоксикаційної, протизапальної терапії, коригувальних засобів. Важливе

\section{СПИСОК ЛІТЕРАТУРИ}

1. Березницкий Я. С. Спонтанный разрыв пищевода - диагностика и лечение / Я. С. Березницкий, А. В. Белов, В. В. Васильченко // Харківська хірургічна школа. - 2012. - № 2 (59). - C. 151-153.

2. Спонтанный разрыв пищевода / В. М. Тимербулатов, М. А. Нартайлаков, А. М. Авзалетдинов, Ш. В. Тимербулатов // Грудная и сердечно-сосудистая хирургия. - 2009. - № 2. - С. 54-58.

3. Выбор хирургической тактики при лечении разрывов пищевода / В. А. Мартинюк, П. П. Шипулин, В. И. Байдан [и др.] // Матеріали міжнар. наук.-практ. конф. “Сучасні проблеми торакальної хірургії”, 21-22 жовтня, 2010 р. - Кіровоград, 2010. - Вип. 1, ч. 1. - С. 57-58.

4. Комплексное хирургическое лечение синдрома Бурхав / В. В. Ганжий, В. И. Перцов, О. Ю. Моряк [и др.] // Матеріали значення надається лікуванню легенево-плевральних та серцевих ускладнень.

У результаті лікування одужували 10 пацієнтів. Серед хворих (8), де проведено зашивання стравохідного дефекту незалежно від його давності, спостерігали значно сприятливіший перебіг післяопераційного періоду. 3 них у 5 випадках після операцій сформувались зовнішні стравохідні нориці за ходом дренажів, що закривались самостійно протягом 28-53 днів. Тричі, при давності розриву менше 48 год, норицеутворення вдалось уникнути.

У двох випадках, де операційна допомога обмежувалась дренуванням плевральних порожнин та виключенням стравоходу, формували езофаго-медіастино-плевроторакальні нориці з вторинними ускладненнями (флегмони грудної клітки, остеомієліт ребра, рецидиви стравохідної кровотечі), що потребували довготривалого лікування та повторних госпіталізацій хворих у стаціонар. Закриття нориць досягнуто консервативно при строках лікування 81 та 112 днів.

Один пацієнт, який госпіталізований у термінальному стані, помер від поліорганної недостатності, спричиненої інтоксикацією без хірургічної допомоги. Ще в одному випадку, де мав місце некроз стінки правого головного бронха, смерть настала на операційному столі.

Висновки. 1. Для ефективного лікування та сприятливого прогнозу при спонтанному розриві стравоходу важливе значення відіграє рання госпіталізація хворих у спеціалізоване відділення. 3 цією метою доцільне ознайомлення 3 даною патологією лікарів (хірургів, пульмонологів, гастроентерологів, кардіологів, лікарів загального профілю), до яких пацієнти найчастіше звертаються на початку.

2. Необхідною $є$ рання, агресивна хірургічна тактика, яка полягає в зашиванні розриву стравоходу, його виключенні та адекватному дренуванні середостіння та плевральної порожнини.

міжнар. наук.-практ. конф. “Сучасні проблеми торакальної хірургіі”, 21-22 жовтня, 2010 р. - Кіровоград, 2010. - Вип. 1, ч. 1. - С. 25-27.

5. Черноусов А. Ф. Хирургия пищевода : Руководство для врачей / А. Ф. Черноусов, П. М. Богомольский, Ф. С. Чурбанов. - М. : Медицина, 2000. - 341 с.

6. Management algorithm for esophageal perforation / J. Kiev, M. Amendola, D. Bouhaidar // Am. J. Surg. - 2007. - Vol. 194. - P. 103-106.

7. Management of Esophageal Perforation in Adults / Lileswar Kaman, Javid Iqbal, Byju Kundil, Rakesh Kochhar // Gastroenterology Research. - 2010. - Vol. 3(6). - P. 235-244.

8. Primary esophageal repair for Boerhaave's syndrome / D. R. Lawrence, S. K. Ohri, R. E. Moxon [et al.] // Ann. Thorac. Surg. 1999. - Vol. 67. P. 818-820. 